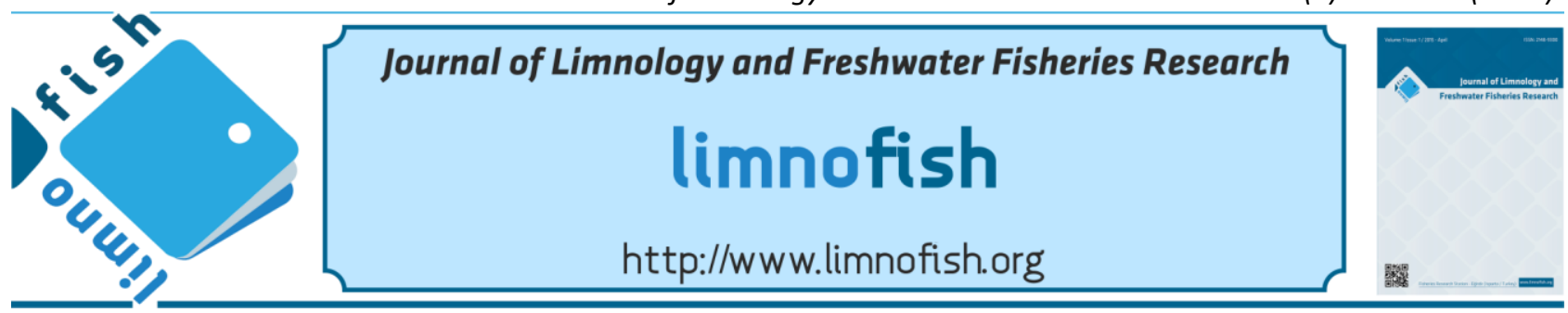

\title{
Effect of Different Feed and Stocking Density on Survival and Growth Performance of Astacus leptodactylus (Esch., 1823) Juveniles
}

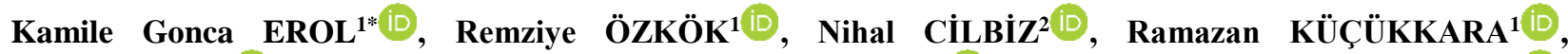

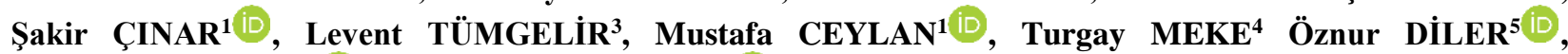 \\ Behire Ișil DİDINEN ${ }^{5}$ (i) , Seval BAHADIR KOCA ${ }^{5(i)}$
}

${ }^{1}$ Eğirdir Fisheries Research Institute, 32500 Eğirdir, Isparta, Turkey

${ }^{2}$ Ministry of Food, Agriculture and Livestock, Food Control Laboratory Directorate, 32200 Isparta, Turkey

${ }^{3}$ Ministry of Food, Agriculture and Livestock, County Directorate, 09760 Bozdoğan, Aydın, Turkey

${ }^{4}$ Ministry of Food, Agriculture and Livestock Directorate of Isparta Province, 32200 Isparta, Turkey

${ }^{5}$ Süleyman Demirel University, Eğirdir Fisheries Faculty, 32260 Isparta, Turkey

\section{A B S T R A C T}

The aim of this study was to investigate the combined effects of two stocking densities (650 and 1300 juveniles $/ \mathrm{m}^{2}$ ) and diets (live feed - Daphnia magna and commercial trout feed) on survival rate and growth performance of Astacus leptodactylus juveniles. Juveniles in the second developmental stage were used in the experiment. Final survival rate and growth paremeters of juveniles were evaluated at the end of experiment (90 days). The results of this study indicated that diets were not found effective on survival rates, though increasing stock densities reduced survival rates. The best final survival rate as $21.99 \%$, was achieved in the group fed with live feed and kept under the 650 juveniles $/ \mathrm{m}^{2}$ stocking density, whereas the lowest survival rate values as $10.84 \%$ was obtained in the group fed with trout pellet and kept under the 1300 juveniles $/ \mathrm{m}^{2}$ stocking density. At the end of experiment, the highest final body weight was found in group of at 650 juveniles $/ \mathrm{m}^{2}$ stocking density and fed with trout feed. The result of our study also revealed that stocking density had a significant effect on survival rates of crayfish juvenile fed with both feeds.

\section{ARTICLE INFO}

\section{RESEARCH ARTICLE}

Received : 05.04.2017

Revised : : 16.10.2017

Accepted : :02.11.2017

Published : 29.12.2017

DOI: 10.17216/LimnoFish.304140

* CORRESPONDING AUTHOR

gonca_erol@hotmail.com

Tel : +90 2463133460

Keywords: Astacus leptodactylus, feeding, stocking density, survival rate, growth

Farklı Yem ve Stok Yoğunluğunun Astacus leptodactylus (Esch., 1823) Juvenillerinin Hayatta Kalma ve Büyüme Performansı Üzerine Etkisi

Öz: Bu çalışmada, iki farklı yem (canlı yem-Daphnia magna ve ticari alabalık yemi) ve stok yoğunluğunun (650 ve 1300 juvenil/ $\mathrm{m}^{2}$ ) Astacus leptodactylus yavrularının hayatta kalma ve büyüme performansı üzerine kombine etkileri araştırılmıştır. Denemede II. dönem yavrular kullanılmıștır. Deneme sonunda, yavruların hayatta kalma ve büyüme parametreleri değerlendirilmiștir. Bu çalışmanın sonuçları, diyetlerin hayatta kalma oranları üzerinde etkili olmadığını, ancak artan stok yoğunluğunun yaşama oranlarını azalttığını göstermiştir. En iyi yaşama oranı \% 21,99 olarak 650 juvenil $/ \mathrm{m}^{2}$ stok yoğunluğunda canlı yemle beslenen grupta sağlanırken, en düşük yaşama oranı ise \% 10,84 olarak 1300 juvenil $/ \mathrm{m}^{2}$ stok yoğunluğunda alabalık yemi ile beslenen grupta elde edilmiş̧ir. Denememe sonunda en yüksek vücut ağırlığı, 650 juvenil $/ \mathrm{m}^{2}$ stok yoğunluğunda alabalık yemi ile beslenen grupta bulunmuştur. Çalışmamız sonucunda ayrıca, yavru kerevit beslenmesinde her iki yem ile beslenen yavrularda hayatta kalma oranları üzerinde stok yoğunluğunun önemli bir etkiye sahip olduğu görülmüştür.

Anahtar kelimeler: Astacus leptodactylus, besleme, stok yoğunluğu, yaşama oranı, büyüme

How to Cite

Erol KG, Özkök R, Cilbiz N, Küçükkara R, Çınar Ş, Tümgelir L, Ceylan M, Meke T, Diler Ö, Didinen BI, Bahadır Koca S. 2017. Effect of Different Feed and Stocking Density on Survival and Growth Performance of Astacus leptodactylus (Esch., 1823) Juveniles 3(3):159-165. doi: 10.17216/LimnoFish.304140

\section{Introduction}

The narrow-clawed crayfish, also known as Turkish crayfish, Astacus leptodactylus, is the native freshwater crayfish species of Turkey (Holdich 2002). A. leptodactylus has a widespread distribution in lakes and ponds in many parts of the country. Its 
distribution area was considerably expanded in Turkey after 1985 because of its commercial importance and declined catches from traditional fisheries. Although the domestic demand for crayfish was very low in Turkey, this country has been the main supplier of A. leptodactylus to Western Europe from 1970 to until 1986 (Harlıoğlu 2004, 2008). Until 1984, A. leptodactylus had an important role as an export product. But after 1985, Crayfish production declined dramatically (from 5000 tonnes to 200 tonnes) (Bolat 2001). The main cause of the decrease in crayfish production was the outbreak and spread of crayfish plague, caused by the funguslike organism, Aphanomyces astaci, excessive crayfish harvesting, pollution of water in lakes and overfishing (Bolat 2001; Svoboda et al. 2012, 2014).

Crayfish culture can vary in intensity, from extensive to intensive rearing systems. However, intensive (completely closed) crayfish culture is not practically used in Europe. As a matter of fact, this culture has not proved economically profitable due to high mortality caused by cannibalism amongst cultured crayfish and to high production costs (Kozák et al. 2015). Several environmental factors, such as water temperature, water quality, nutrition, light intensity, photoperiod and density, affect growth and survival of juveniles in intensive crayfish culture (Köksal 1985, 1988; Köksal et al. 1992; SáezRoyuela et al. 2007; Erol et al. 2010). Among these factors, nutrition is one of the most important factors directly affecting the growth of crayfish (Taugbol and Skurdal 1992; Austin et al. 1997; Savolainen et al. 2004; Mazlum 2007; Sáez-Royuela et al. 2007). Several variables (water quality, the quality and amount of food, food supply frequency, its availability to the crayfish) have played significant roles in crayfish culture since the crayfish are totally dependent on supplemental food in intensive culture systems.

Several studies have been carried out under controlled conditions to evaluate the effect of feed on growth and survival of crayfish juveniles and a wide variety of foods have been tested in juveniles from the onset of exogenous feeding. Artemia, Chlorella, chironomid larvae, Daphnia, earthworms, fresh fish meat, aquatic plants and vegetables have been tried by Köksal (1985), Celada et al. (1989, 1993), Taugbol and Skurdal (1992), Köksal et al. (1992), Blake et al. (1994), Oliveira and Fabiao (1998), Verhoef et al. (1998), Verhoef and Austin (1999), Zaikov et al. (2000), Sáez-Royuela et al. (2001, 2007), Savolainen et al. (2003), González et al. (2008). Besides the exogenous feeding, commercial feeds for crustacean and fish species (Taugbol and Skurdal, 1992; Celada et al. 1993;
Sáez-Royuela et al. 1995, 2001; Mazlum 2007) and experimental dry pellets for crayfish and crustaceans (Celada et al. 1989; Savolainen et al. 2004; Ulikowski et al. 2006), have been used in feeding of crayfish juveniles. The results in these studies carried under controlled conditions indicated that the survival and growth of crayfish juveniles have shown a great variability. In addition, it was also stated that the high mortalities were observed in the first period of the independent life of juveniles (Sáez-Royuela et al. 1995; Ulikowski et al. 2006).

In addition to feeding, stocking density is another important factor affecting crayfish growth and survival (Naranjo-Paramo et al. 2004; Ulikowski et al. 2006; Mazlum 2007). Studies under controlled conditions indicated that crayfish growth and survival decreased with increasing stocking density (Naranjo-Paramo et al. 2004; Savolainen et al. 2004; Ulikowski and Krzywosz 2004; Ulikowski et al. 2006; Mazlum 2007; Harlıoğlu 2009; González et al. 2010). In addition, effects of aggressiveness and cannibalism rise with increasing stocking density, resulting in reductions in survival and growth rates, as well as lack of chelae (Savolainen et al. 2004; Mazlum 2007; González et al. 2010).

Several studies have evaluated the effects of different stocking densities on growth and survival of A. leptodactylus (Köksal 1985; Ulikowski and Krzywosz 2004; Ulikowski et al. 2006; Mazlum 2007; Harlıoğlu 2009). However, little is known about the combined effect of feeding and density on the growth and survival of A. leptodactylus juveniles. The aim of this study was to evaluate the impact of feed type and stocking density on growth and survival of A. leptodactylus juveniles.

\section{Materials and Methods \\ Experimental conditions}

This study was carried out in the hatchery of Eğirdir Fisheries Research Institute in 2008. The material for the study consisted narrow-clawed crayfish, A.leptodactylus juveniles.

The juveniles were reared from ovigerous females of A. leptodactylus kept under the laboratory conditions. Ovigerous females were obtained from Lake Eğirdir in April and May 2008 and were placed in breeding tanks in order to obtain the juvenile crayfish. The eggs hatched in the second week of June. Stage 2 juvenile crayfish were fed with Artemia nauplii and Chlorella sp. during one week period. The juveniles with mean weight ( $35 \pm 0.005 \mathrm{mg})$, total length $(11.67 \pm 0.47 \mathrm{~mm})$ and carapace length $(5.87 \pm 0.35 \mathrm{~mm})$ were used in the experiment lasting for 90 -days period. 


\section{Experimental design}

The experimental design consisted of two different feed types (live Daphnia magna and commercial trout feed) and two different stocking densities (650 juveniles $/ \mathrm{m}^{2}$ and 1300 juveniles $\left./ \mathrm{m}^{2}\right)$ in triplicates. The stage 2 juveniles were randomly stocked into 12 rearing tanks with a bottom area 1.5 $\mathrm{m}^{2}$ (975 and 1950 juveniles in each tank at lower and higher stocking density, respectively).

Experimental groups: (D650) crayfish fed with D. magna and stocked 650 juveniles $/ \mathrm{m}^{2}$; (D1300) crayfish fed with D. magna and stocked 1300 juveniles $/ \mathrm{m}^{2}$; (T650) crayfish fed with trout feed and stocked 650 juveniles $/ \mathrm{m}^{2}$; (T1300) crayfish fed with trout feed and stocked 1300 juveniles $/ \mathrm{m}^{2}$.

The experiment was conducted for 90 days. The measurements of carapax, total length, and weight of the juveniles were performed both at beginning (100 individuals) and at the end of the experiment (all individuals). The number of surviving juveniles in each tank was counted at the end of experiment. The specific growth rate (SGR, \%/day) and survival rate were calculated as follows:

$$
\operatorname{SGR}(\% / \text { day })=\frac{100\left(\ln W_{t}-\ln W_{0}\right)}{t}
$$

$W_{t}$ and $W_{0}$ are the final and initial mean weights of juveniles, respectively, and $t$ is the time in days ( $t=90$ day).

$$
\text { Survival rate }(\%)=\frac{\text { final number of crayfish }}{\text { initial number of crayfish }} \times 100
$$

\section{Experimental tanks and water quality management}

Twelve circular fiberglass tanks with $1.5 \mathrm{~m}^{2}$ bottom area in flow-through system were used in the experiment. Severel bricks (29x19x13.5cm) with 42 holes were placed in each tank as shelter. Each tank had its own water inlet and outlet. The quality parameters of the incoming water were: $\mathrm{pH} 7.57$, calcium $54.04 \mathrm{mg} / \mathrm{L}$, magnesium $58.66 \mathrm{mg} / \mathrm{L}$, total hardness $338.65 \mathrm{mg} / \mathrm{L}, \mathrm{O}_{2} 4.99 \mathrm{mg} / \mathrm{L}$. One third of the water in each tank was exchanged every day and aeration was continuously supplied with an airstone in each tank. During the experimental period, water temperature, dissolved oxygen concentration and $\mathrm{pH}$ were measured once daily in each tank with a WTW 340i. The temperature ranged from 17 to $19^{\circ} \mathrm{C}$; dissolved oxygen from 6 to $7 \mathrm{mg} / \mathrm{L}$ and $\mathrm{pH}$ from 7.5 8 .

\section{Feed materials and feeding}

Two different feed types as D. magna and commercial trout feed $(800-1000 \mu)$ were used in the experiment. Commercial trout feed was obtained from a feed manufacturing company. D. magna were cultured in outdoor ponds. The proximate composition of commercial trout feed and D. magna is shown in Table 1. Moisture contents were detected with an automatic moisture analyzer (AND MX-50). The crude protein contents according to Kjeldahl method (Nx6,25) (AOAC 2000a), crude lipid contents by Bligh and Dyer (1959)'s method and crude ash contents according to (Lovell 1981) were done. Crude fibre content was determined according to Standard Association of Official Analytical Chemists (AOAC) methods (AOAC 2000b).

During the experiment, crayfish juveniles were fed daily ad libitum with the experimental diets and waste of feed and feces were removed from the tanks by siphoning.

Table 1. Proximate composition (\%) of Daphnia magna and commercial trout feed used in the experiment

\begin{tabular}{lcc}
\hline Parameter & Daphnia manga & Trout feed \\
\hline Crude protein $(\%)$ & 42.05 & 55 \\
Crude lipid (\%) & 16.2 & 13 \\
Crude cellulose $(\%)$ & 13.5 & 1.5 \\
Crude ash $(\%)$ & 14.7 & 12 \\
\hline
\end{tabular}

\section{Data collection and statistical analysis}

The weight and length of crayfish were measured at the beginning and end of the experiment. Total body length and carapace length were measured with digmatic calliper (to the nearest $0.01 \mathrm{~mm}$ ) and weight measurement were performed by using digital scale with $0.01 \mathrm{~g}$ sensitivity. Significant differences among treatment groups were tested by one-way ANOVA and Duncan's multiple range tests at 5\% level of significance by applying SPSS (version 11) software.

\section{Results}

At the end of 90-days experiment, it was determined that the mean survival rates, final weights, total lengths, carapace lengths and specific growth rates of $A$. leptodactylus juveniles ranged 10.84-21.99\%, 367-653 mg, 23.71-28.68 mm, 12.24$14.70 \mathrm{~mm}, 2.61-3.22 \%$, respectively (Table 2). It was seen that the difference between the values of average length and weight obtained from all groups was statistically significant $(\mathrm{P}<0.05)$. The juveniles fed with trout feed showed a better growth compared to the juveniles fed live feed. The best growth performance was seen on juveniles with low density and with fed trout feed. Both final weights and total lengths in juveniles were negatively affected by increased stocking density.

The highest values $(3.22 \%$ and $3.07 \%)$ in specific growth rate were obtained in the groups fed with trout pellet, whereas the lowest values $(2.64 \%$ and $2.61 \%$ ) were obtained in the groups fed with live feed. It was shown that $S G R$ was statistically 
different between trout feed and live feed groups, but stocking density formed in the relevant groups did not exhibited significant differences on $S G R$.

Survival rates varied from $10.84 \%$ to $21.99 \%$. Survival of the juveniles decreased with increased stocking density (Table 2). The best survival rate as $21.99 \%$, was achieved in the group fed with live feed and kept under the low stocking density, whereas the lowest survival rate values as $10.84 \%$ was obtained in the group fed with trout pellet and kept under the high stocking density. The survival rates of reduced with increasing stocking density. The results indicated that stocking density had a significant impact on the survival rate of crayfish juveniles.

Table 2. Final survival and growth indices of juvenile crayfish in the end of experiment $(\bar{X} \pm \mathrm{SD})$.

\begin{tabular}{lcccc}
\hline \multirow{2}{*}{ Parameters } & \multicolumn{3}{c}{ Experimental groups } \\
\cline { 2 - 5 } & $24.04 \pm 3.23^{\mathrm{c}}$ & $23.71 \pm 3.13^{\mathrm{d}}$ & $28.68 \pm 4.55^{\mathrm{a}}$ & $27.71 \pm 4.46^{\mathrm{b}}$ \\
\hline Total length (mm) & $12.39 \pm 1.72^{\mathrm{c}}$ & $12.24 \pm 1.80^{\mathrm{d}}$ & $14.70 \pm 2.57^{\mathrm{a}}$ & $14.09 \pm 2.38^{\mathrm{b}}$ \\
Carapax length (mm) & $367 \pm 1.181^{\mathrm{c}}$ & $368 \pm 0.168^{\mathrm{d}}$ & $653 \pm 0.321^{\mathrm{a}}$ & $570 \pm 0.341^{\mathrm{b}}$ \\
Weight (mg) & $2.64 \pm 0.005^{\mathrm{b}}$ & $2.61 \pm 0.16^{\mathrm{b}}$ & $3.22 \pm 0.13^{\mathrm{a}}$ & $3.07 \pm 0.006^{\mathrm{a}}$ \\
$S G R(\% /$ day) & $21.99 \pm 2.32^{\mathrm{a}}$ & $14.25 \pm 1.38^{\mathrm{b}}$ & $20.67 \pm 3.13^{\mathrm{a}}$ & $10.84 \pm 2.53^{\mathrm{b}}$ \\
Survival rate (\%) & & & &
\end{tabular}

Mean values in rows with different superscripts are significantly different $(\mathrm{P}<0.05)$.

\section{Discussion}

Several researchers stated that the juvenile astacids had the poor survival or growth rates when they were fed dry diets as the only food from the onset of exogenous feeding (Taugbol and Skurdal 1992; Ulikowski et al. 2006; Sáez-Royuela et al. 2007; González et al. 2009). For instance, a mortality of $83-90 \%$ in noble crayfish juveniles were recorded with feeding a dry pellets (Taugbol and Skurdal, 1992). They observed that when juveniles were fed with fish and potatoes in addition to dry pellets, mortality was reduced to about $70 \%$. Similarly, Sáez-Royuela et al. (2007) recorded a mortality of $88.7 \%$ after 100 days when juveniles did not receive live feed. According to the results of these studies, the researchers advised to use the live feed as supplement from the onset of external feeding to guarantee the viability of juvenile crayfish. González et al. (2008), supplementing a dry diet with live Artemia nauplii in excess, obtained good results (1283 mg weight, $4459 \%$ weight gain and $3.82 \%$ SGR) for juvenile Pacifastacus leniusculus. González et al. (2011) indicated that the juvenile crayfish $(P$. leniusculus) receiving decapsulted Artemia cysts up to day 50 as supplement to a dry diet showed a faster growth (averaging $13.8 \mathrm{~mm}$ carapace length, $610 \mathrm{mg}$ weight $3.05 \% \mathrm{day}^{-1} \mathrm{SGR}$ ) at the end of the experiment. In contrast to these results, the commercial trout feed used in the present study resulted in a better growth performance ( $28.68 \mathrm{~mm}$ total length and $653 \mathrm{mg}$ alive weight) than live feed. However, similar survival rates (20.67-21\%) were obtained with both live feed and commercial trout feed. These results suggest that good growth can be achieved by using manufactured diets. This diet or one of similar composition may also constitute a good reference for future dietary studies. Similarly, Verhoef et al. (1998) using a variety of natural and an artificial diet, found similar results for juvenile yabbies Cherax destructor. The researchers indicated that the commercial diet used in their study produced growth rates similar to those obtained by feeding live or frozen zooplankton.

Köksal (1985), obtained relatively good survival and growth rates $(44.23 \%$ and $430.64-476.16 \mathrm{mg}$ respectively) after 90 days in A. leptodactylus juveniles fed trout pellet and flamentous green algae. In our study performed during the same period, the growth of crayfish was better than that reported by Köksal (1985), but the survival rates of juveniles were lower. This may be due to the higher stocking density. In 1985, the same researcher, using different food type in feeding of stage 4 juveniles of A. leptodactylus (mean total length $21.1 \mathrm{~mm}$ ) at the same density, obtained total lengths of 29.2$37.4 \mathrm{~mm}$, weights of $623-1216 \mathrm{mg}$ and survival rates of 50.6-72.4\% after 60 days. In the present experiment, stage 2 juveniles (mean size $11.67 \mathrm{~mm}$ ) reached 23.71-28.68 $\mathrm{mm}$ length and $367-653 \mathrm{mg}$ weight after 90 days. However the survival rates of juveniles were lower the levels reported by Köksal (1985). It is noteworthy that initial sizes used for this study (stage 4 juveniles) were higher than size in our experiment (stage 2 juveniles). The lower survival rates may be due to the initial size of the juveniles used in the experiment. The second-stage that the juveniles become independent from the mother is critical period for crayfish and the highest mortality during the rearing of crayfish occurs in this period but fell considerably during ensuing periods (Ulikowski et al. 2006). 
In the present study, crayfish juveniles fed trout feed showed a higher specific growth rate compared to juveniles fed live feed. Sáez-Royuela et al. (2007) indicated that $P$. leniusculus juveniles fed a dry diet (for salmonids) supplemented with live feed (Artemia nauplii or Daphnia) had a higher $S G R$ value (2.83) those fed a dry diet as the sole food (2.24). Ulikowski et al. (2006) used experimental pellets in the feeding of juvenile crayfish and obtained $S G R$ ranging from 1.3 (for the third month) to $6.4 \%$ (for the first month) for A. leptodactylus. In a similar study of the same species by Harlıoglu (2009), SGR values were found to be $2.41-2.48 \%$ for A. leptodactylus when crayfish were provided with natural food. Zaikov et al. (2000), used four different diets for A. leptodactylus during up to 1 month of age under 4 diet variants: zooplankton, feed mixture, meat and soyabean meal, and reported the best results of $S G R$ in A. leptodactylus fed with zooplankton diet $(3.56 \%)$ and fed mixture diet (3.15\%). González et al. (2008), supplementing a dry diet with live Artemia nauplii in excess, obtained $3.82 \% S G R$ for juvenile P. leniusculus.

It has been reported that increased stocking density has a certainly negative impact on crayfish growth and survival in previous studies (Ulikowski and Krzywosz 2004; Savolainen et al. 2004; Ulikowski et al. 2006; Mazlum 2007; González et al. 2010). Savolainen et. al. (2004) indicated that final mean weight and mean length in P. leniusculus were decreased with increasing stocking densities. The researchers also predicted a reduction of crayfish survival $11 \%$ when stocking density was doubled. The decrease rates of survival when stocking density was doubled in our study for A. leptodactylus juveniles were much higher (35.2\% for the live feed groups and $47.5 \%$ for the trout feed groups). The reason of this might be that we had a higher initial stocking densities. In $P$. leniusculus, González et al. (2010) reported $86.33 \%$ and $39.3 \%$ survival in the lowest and highest stocking densities (100 and $1000 / \mathrm{m}^{2}$ ) respectively, after 100 days. Ulikowski et al. (2006) reported the high mortality rate of 48-77 \% in P. leniusculus and A. leptodactylus at different stocking densities (600, 1200 juveniles $/ \mathrm{m}^{2}$ ). Harlıoğlu (2009) reported survival and $S G R$ for the same species from $34,3 \%$ to $56 \%$ and 1.10 to 1.40 respectively at different stocking densities, ranging from 234 juveniles $/ \mathrm{m}^{2}$ to 937 juveniles $/ \mathrm{m}^{2}$. Köksal (1985) reported survival rates of 22.5-58\% and at different stocking densities (130260 juveniles $/ \mathrm{m}^{2}$ ) in A. leptodactylus. The length of weight of juveniles ranged from 20.13 to $20.9 \mathrm{~mm}$ and from 201.33-210.5 mg after 45 days, respectively. Ulikowski and Krzywosz (2004) obtained good results in A. leptodactylus after fourweek rearing period. The survival was $70 \%$ (initial density: 300 juveniles $/ \mathrm{m}^{2}$ ), 58\% (initial density: 600 juveniles $/ \mathrm{m}^{2}$ ) and $47.8 \%$ (initial density: 1200 juveniles $/ \mathrm{m}^{2}$ ). Harlıoğlu (2009) obtained 57.3$62.6 \%, 51.3-56.6 \%$, and $42-44.3 \%$ survival for $A$. leptodactylus at stocking densities of 234,468 , and 937 juveniles $/ \mathrm{m}^{2}$, respectively. Mazlum (2007) reported good growth rate and survival for newly hatched third instars A. leptodactylus at stocking densities of 50, 100 and $200 / \mathrm{m}^{2}$. In the present study, growth and survival of crayfish juveniles were affected by stocking density; they decreased as initial stocking density increased. This is in accordance with results on P. leniusculus (Savolainen et al. 2004; González et al. 2010), A. leptodactylus (Ulikowski and Krzywosz 2004; Mazlum 2007). Harlıoğlu (2009) stated that crayfish exhibit density dependent growth even in situations where sufficient food resources are available. The results obtained in our study also support this view. The values of growth obtained in our study for A. leptodactylus were similar to those achieved in other studies with similar or even much lower stocking densities; P. leniusculus in densities 100-800 individuals $/ \mathrm{m}^{2}$ (Savolainen et al. 2004), A. leptodactylus and $P$. leniusculus in densities 600-1200 individuals $/ \mathrm{m}^{2}$ (Ulikowski et al. 2006), for $P$. leniusculus in densities 100-1000 individuals $/ \mathrm{m}^{2}$ (González et al. 2010). Regarding the survival, the values obtained in our experiment was much lower than the levels of the same species reported by other authors (Köksal 1985; Ulikowski et al. 2006; Mazlum 2007; Harlığlu 2009). The poor survival rates may be related to the initial stocking density and initial weight and length of the juveniles. In addition, this is due to the food, experimental conditions, and the number of the available shelters.

In conclusion, the crayfish juveniles fed with trout feed exhibited better growth performance than those fed with live feed. This suggest that it might be better to develop an artificial diet for use in the intensive culture of juvenile astacid juvenile crayfish. In addition, the survival of juvenile crayfish were negatively affected by increased stocking density. The best survival rate was obtained at 650 juveniles $/ \mathrm{m}^{2}$ stocking density. This study has clearly demonstrated that stocking density had a significant effect on survival rates of crayfish juveniles.

\section{Acknowledgements}

This study was financially supported by General Directorate of Agriculturel Research and Policies with TAGEM/HAYSÜD/32132 project. The authors would like to thank the the staff of Eğirdir Fisheries Research Institute. 


\section{References}

AOAC 2000a. Official Method 940.25 Nitrogen (Total) in Seafood. First Action 1940, Official Methods of Analysis of AOAC International $17^{\text {th }}$ Edition.

AOAC 2000b. Official methods of analysis 16th ed. Association of Official Analytical Chemists, Arlington (VA), USA

Austin C.M, Jones P.L, Stagnitti F, Mitchell B.D. 1997. Response of the yabby, Cherax destructor clark, to natural and artificial diets: phenotypic variation in juvenile growth. Aquaculture. 149(1-2):39-46. doi:10.1016/S0044-8486(96)01429-9

Blake M, Nystrom P, Hart P. 1994. The effect of weed cover on juvenile signal crayfish (Pacifastacus leniusculus Dana) exposed to adult crayfish and non-predatory fish. Ann Zool Fenn. 31(3): 297-306.

Bligh, E.G, Dyer W.J. 1959. A Rapid Method of Total Lipid Extraction and Purification, Can J Biochem Phys. 37(8): 911-917. doi:10.1139/y59-099

Bolat Y. 2001. An estimation in the population density of freshwater crayfish (Astacus leptodactylus salinus, Normdan 1842) living in Hoyran area of Eğirdir Lake [PhD thesis] The University of Süleyman Demirel. 116 pp.

Celada J.D, Carral J.M, Gaudioso V.R, Temino C, Fernandez R. 1989. Response of juvenile freshwater crayfish (Pacifastacus leniusculus Dana) to several fresh and artificially compounded diets. Aquaculture. 76(1-2): 67-78. doi:10.1016/0044-8486(89)90252-4

Celada J.D, Carral J.M, Gaudioso V.R, González J, LopezBaisson C, Fernandez R. 1993. Survival and growth of juvenile freshwater crayfish Pacifastacus leniusculus Dana fed two raw diets and two commercial formulate feeds. J World Aquacult Soc. 24(1):108-111. doi:10.1111/j.1749-7345.1993.tb00157.x

Erol KG, Özkök R, Küçükkara R, Çınar Ş. 2010. Potential mortality causes on juvenile stage in freshwater crayfish Astacus leptodactylus (Eschscholtz, 1823) farming. SDU-ESUFD. 6(2):23-30.

González A, Celada JD, González V, García V, Carral JM, Sáez-Royuela M. 2008. Artemia nauplii and two commercial replacements as dietary supplement for juvenile signal crayfish, Pacifastacus leniusculus (Astacidae), from the onset of exogenous feeding under controlled conditions. Aquaculture. 281(1-4):83-86. doi:10.1016/j.aquaculture.2008.06.015

González R, Celada JD, Carral JM, González A, Sáez-Royuela M, García V. 2009. Decapsulated Artemia cysts as dietary supplement for juvenile crayfish (Pacifastacus leniusculus, Astacidae) at different food supply frequencies from the onset of exogenous feeding under controlled conditions. Aquaculture. 295(3-4):200-204.

doi:10.1016/j.aquaculture.2009.07.009
González R, Celada JD, García V, Carral JM, SáezRoyuela M. 2010. Stocking density for the intensive rearing of juvenile crayfish, Pacifastacus leniusculus (Astacidae), using Artemia nauplii to supplement a dry diet from the onset of exogenous feeding. Aquacult Int. 18(3):371-378. doi:10.1007/s10499-009-9250-x

González A, Celada JD, Carral JM, Sáez-Royuela M, García V, González R. 2011. Additional supply of decapsulated Artemia cysts for various periods in intensive rearing of juvenile crayfish (Pacifastacus leniusculus, Astacidae). Knowl Manag Aquat Eco. 2011(401):15p1-15p2. doi:10.1051/kmae/2011030

Harlığlu M.M. 2004. The present situtation of freshwater crayfish, A. leptodactylus (Eschscholtz, 1823) in Turkey. Aquaculture. 230(1-4):181-187. doi:10.1016/S0044-8486(03)00429-0

Harloğlu M.M. 2008. The harvest of the freshwater crayfish A. leptodactylus Eschscholtz in Turkey: harvest history, impact of crayfish plague, and present distribution of harvested populations. Aquacult Int. 16 (4):351-360. doi:10.1007/s10499-007-9145-7

Harlıoglu MM. 2009. A comparison of the growth and survival of two freshwater crayfish species, Astacus leptodactylus Eschscholtz and Pacifastacus leniusculus (Dana), under different temperature and density regimes. Aquacult Int. 17(1):31-43. doi:10.1007/s10499-008-9177-7

Holdich D.M. 2002. Biology of freshwater crayfish. Oxford:Blackwell Science. 702 pp.

Kozák P, Duriš Z, Petrusek, A, Buřič M, Horká I, Kouba A, Kozubíková-Balzarová E, Policar T. 2015. Crayfish Biology and Culture. University of South Bohemia in České Budějovice, Faculty of Fisheries and Protection of Waters, Vodňany, CZE, $456 \mathrm{p}$

Köksal G. 1985. Production of juvenile Astacus leptodactylus salinus (Nordmann, 1842) in culture conditions. EgeJFAS. 2 (7-8):61-76.

Köksal G. 1988. Astacus leptodactylus in Europe. In: Freshwater Crayfish: Biology, Management and Exploitation (eds D.M. Holdich and R.S. Lowery), Croom Helm Press, pp. 365-400.

Köksal G, Ölmez M, Bekcan S, Güler AS. 1992. Rearing of freshwater crayfish (Astacus leptodactylus Esch. 1823) juveniles for restoration of natural waters. Istanbul Univ J Aqua Product. 1:1-16.

Lovell RT. 1981. Laboratory manuel for fish feed analysis and fish nutrition studies. Department of Fisheries and Allied Aquacultures International Center for Aquaculture. Auburn University. 65p.

Mazlum Y. 2007. Stocking density affects the growth, survival, and cheliped injures of third instars of narrow-clawed crayfish, Astacus leptodactylus Eschscholtz,1823 juveniles. Crustaceana. 80(7):803815.

Naranjo-Paramo J, Hernandez-Liamas A, Villareal H. 2004. Effect of stocking density on growth, survival and yield of juvenile redclaw crayfish Cherax quadricarinatus (Decapoda: Parastacidae) in gravel- 
line commercial nursery ponds. Aquaculture. 242(14):197-206. doi:10.1016/j.aquaculture.2004.05.017

Oliveira J, Fabiao A. 1998. Growth responses of juvenile red swamp crayfish, $P$. clarkii Girard, to several diets under controlled conditions. Aquac Res. 29(2):123-129. doi:10.1046/j.1365-2109.1998.00936.x

Sáez-Royuela M, Carral JM, Celada JD, Muñoz C. 1995. Effects of management on survival and growth of stage 2 juvenile freshwater crayfish (Pacifastacus leniusculus Dana) under laboratory conditions. Aquaculture. 133(2):123-133. doi:10.1016/0044-8486(95)00004-L

Sáez-Royuela M, Carral JM, Celada JD, Pérez JR. 2001. Effects of shelter type and food supply frequency on survival and growth of stage-2 juvenile white-clawed crayfish (Austropotamobius pallipes Lereboullet) under laboratory conditions. Aquacult Int. 9(6): 489-497. doi:10.1023/A:1020509627870

Sáez-Royuela M.S, Carral J.M, Celada J.D, Perez J.R, González A. 2007. Live feed as supplement from the onset of external feeding of juvenile signal crayfish ( $P$. leniusculus Dana. Astacidae) under controlled conditions. Aquaculture. 269(1):321-327. doi:10.1016/j.aquaculture.2007.04.053

Savolainen R, Ruohonen K, Tulonen J. 2003. Effects of bottom substrate and presence of shelter in experimental tanks on growth and survival of signal crayfish (Pacifastacus leniusculus (Dana) juveniles. Aquac Res. 34(4):289-297. doi:10.1046/j.1365-2109.2003.00817.x

Savolainen R, Ruohonen K, Railo E. 2004. Effect of stocking density on growth, survival and cheliped injuries of stage 2 juvenile signal crayfish Pacifastacus leniusculus Dana. Aquaculture. 231(1-4):237-248. doi:10.1016/j.aquaculture.2003.09.045

Svoboda J, Kozubíková E, Kozák P, Kouba A, Bahadir Koca S, Diler Ö, Diler I, Policar T, Petrusek A. 2012.
PCR detection of the crayfish plague pathogen in narrow-clawed crayfish inhabiting Lake Eğirdir in Turkey. Dis Aquat Organ. 98 (3): 255-259. doi:10.3354/dao02445

Svoboda J, Strand D.A, Vralstad T, Grandjean F, Edsman L, Kozák P, Kouba A, Fristad R.F, Koca S.B, Petrusek A. 2014. The crayfish plague pathogen can infect freshwater-inhabiting crabs. Freshwater Biol. 59: 918-929. doi:10.1111/fwb. 12315

Taugbol T, and Skurdal J. 1992. Growth mortality and moulting rate of noble crayfish, Astacus astacus L., Juveniles in aquaculture experiments. Aquac Res. 23(4):411-420. doi:10.1111/j.1365-2109.1992.tb00785.x

Ulikowski D, Krzywosz T. 2004. The impact of photoperiod and stocking density on the growth and survival of narrow-clawed crayfish (Astacus leptodactylus Esch.) larvae, Arch Pol Fish. 12(1):81-86.

Ulikowski D, Krzywosz T, Smietana P. 2006. A comparison of survival and growth in juvenile A. leptodactylus (Esch.) and P. leniusculus (Dana) under controlled conditions. B Fr Peche Piscic. 2006 (380-381):1245-1253. doi:10.1051/kmae:2006023

Verhoef GD, Jones PL, Austin CM. 1998. A comparison of natural and artificial diets for juveniles of the Australian freshwater crayfish Cherax destructor. J World Aquac Soc. 29(2):243-248. doi:10.1111/j.1749-7345.1998.tb00983.x

Verhoef GD, Austin CM. 1999. Combined effects of temperature and density on the growth and survival of juveniles of the Australian freshwater crayfish, Cherax destructor Clark, Part 1. Aquaculture. 170(1):37-47. doi:10.1016/S0044-8486(98)00394-9

Zaikov A, Hubenova-Siderova T, Karanikolov Y. 2000. Growth and survival of juvenile crayfish Astacus leptodactylus Esch., fed different diets under laboratory conditions. Bulg J Agric Sci. 6(3):349-354. 